Caring and Sharing

Tests Between Alternative Models of Intra-Household Allocation

Browning, Martin; Lechene, Valerie

Publication date:

2001

Document version

Early version, also known as pre-print

Citation for published version (APA):

Browning, M., \& Lechene, V. (2001). Caring and Sharing: Tests Between Alternative Models of Intra-Household Allocation. Department of Economics, University of Copenhagen. 


\section{DISCUSSION PAPERS Department of Economics University of Copenhagen}

\section{1-07}

Caring and Sharing: Tests Between Alternative Models of Intra-Household Allocation

Martin Browning

Valérie Lechene

Studiestræde 6, DK-1455 Copenhagen K., Denmark

Tel. +45 35323082 - Fax +45 35323000

http://www.econ.ku.dk 


\title{
Caring and Sharing: Tests Between Alternative Models of Intra-household Allocation.
}

\author{
Martin Browning ${ }^{\alpha}$ \\ University of Copenhagen \\ Martin.B rowning@econ.ku.dk \\ Valérie Lechene \\ Oxford University
}

A pril 27, 2001

\begin{abstract}
A bstract
Several models of intra-household decision making have been suggested in the literature. One important dichotomy is between non-cooperative and cooperative models (including speci..c models of bargaining). The other important distinction is between models that allow for caring and those that do not. We present a framework that includes all suggested models and variants as special cases. We derive the theoretical predictions of these models for the relationship between expenditures on goods and the intra-household distribution of income. We estimate and test between these relationships using Canadian household expenditure data. We conclude that there is evidence that both husbands and wives care for each other in the sense that with an unequal distribution of incomes the high income partner behaves as a 'Becker dictator' and there is local income pooling. We further ..nd that for about half of the households in our sample (those with more equal incomes) a re-distribution of income would lead to changes in budget allocations. We conclude that the data are consistent with a collective model with caring partners.
\end{abstract}

${ }^{x}$ We gratefully acknowledge the contribution of Wasif Rasheed to the research presented in this paper. We are also grateful to Andrew Chesher, Philippe Jéhiel, Arthur Lewbel and participants at seminars at Inra, Ceras, Bristol, Nuc eld, Copenhagen and at ESEM in Toulouse for comments and discussion. We thank the Canadian SSHRC and the Danish Social Science R esearch Foundation (SSF) for support. 
K eywords: intra-household allocation, altruism, cooperative behaviour, non cooperative behaviour.

\section{Introduction}

There is now considerable empirical evidence that the distribution of income within the household makes a dixerence to many household outcomes (see, for example, B ourguignon, Browning, Chiappori and Lechene (1993), B rowning (1995), Browning, Bourguignon, Chiappori and Lechene (1994), Lundberg, Pollak and Wales (1995), Phipps and Burton (1992), Schultz (1990) and Thomas (1990)). This universal rejection of 'income-pooling' contradicts one of the basic predictions of the 'unitary' model of household behaviour that posits that the household behaves as though it has a single objective function. These empirical ..ndings, coupled with the methodological unease that arises from treating an aggregate, the household, as though it is an individual has lead to a burgeoning literature on intra-household models. There has not been, however, much work on exactly which model best describes what goes on inside the household. In this paper we present a framework that allows us to capture several of the theoretical models suggested in the literature as special cases. Dixerent models give dixerent empirical predictions for the relationship between demands and the distribution of income within the household. We derive these predictions and provide empirical tests between them.

Once we allow that individuals within the household may have dixerent preferences over how to allocate the time and money available to the household we need to specify a model of within household decision making. In doing this, all investigators in economics adopt a 'B eckerian' framework in which each person in the household has a utility function de..ned over household outcomes (see Becker (1991) for a de...nitive statement). The dixerent models vary in how they allow for the dependence of household outcomes on these preferences. Basically there are four broad options for theoretical models: assuming enough to give a single utility function (unitary) model (see, for example, Becker (1991) and Samuelson (1956)); adopting a bargaining model (see, for example, M anser and Brown (1980), M cElroy and Horney (1981), Lundberg and Pollak (1993) and Rasheed (1996)); taking a model which assumes only et ciency (the 'collective' model) (see, for example, A pps and Rees (1988), Chiappori (1988) and (1992) and Browning and Chiappori (1997)) or adopting some non-cooperative model (see, for example, Leuthold 
(1968), Bourguignon (1984), Ulph (1988), Woolley (1993), Browning (1994) and Konrad and Lommerud (1995)).

There has been some structural empirical work using one or other model. In this work speci..cation testing has been con..ned to general speci..cation tests or to tests of speci..c predictions of the model used. Sometimes, however, the pre diction is not unique to that model (formally, we cannot identify which model is generating our data). The obvious example is the rejection of income pooling which is generally common to all non-unitary models. The only empirical testing between dixerent non-unitary models is that of Kapteyn and Kooreman (1990); they test between bargaining models, with varying power for both partners, from "male dictatorship" to "female dictatorship", using a linear Engel curve speci..cation. In this paper we present tests between the unitary model and one variant of each of the broad classes of models (bargaining, collective and non-cooperative). The testing is based on a general Engel curve analysis which voids the linearity assumption of Kapteyn and Kooreman (1990). ${ }^{1}$ As well as testing between various models we also derive and implement tests for the presence of 'caring' (in the speci..c Becker sense given below) within the household.

\section{Theory}

\subsection{Framework}

We consider a two person ( $I=A$; $B$ with $A$ being a 'she' and $B$ being a 'he') household which faces ..xed prices (which we normalise to unity) and allocates a given total expenditure among dixerent goods. In the conventional unitary model we assume the existence of a household utility function and maximise this subject to the budget constraint. If we drop the assumption that there is a household utility function then we need to posit some other household decision process. To stay within the conventional neo-classical (Beckerian) framework, we assume in all that follows that goods are either public or private and that each person has a representable preference ordering over the within household allocation of goods. Formalising, suppose that any good can either be used privately by one or other person in the household or it is public ${ }^{2}$. Denote person I's vector of their private

\footnotetext{
${ }^{1}$ We do not attempt to exploit the price variation that we have in the data. For results on the collective model versus the unitary model using price variation, see Browning and Chiappori (1996).

${ }^{2}$ We could allow that goods have the possibility of having both a private and a public nature; this complicates the notation without adding much.
} 
good by $q^{\prime}$ and let the vector of public goods be denoted $Q$. Let $q=q^{A}+q^{B}$ be the vector of household consumption of the private good.

The household budget constraint is:

$$
Q^{0} e+q^{0} e=x
$$

where $\mathrm{e}$ is the appropriately sized unit vector and $\mathrm{x}$ is household total expendi $\mathrm{C}_{\mathrm{C}}$ ture. The most general form for the individual preferences is $u^{\prime}=\dot{A}^{\prime}{ }^{\prime} q^{A} ; q^{B} ; Q$ so that each person cares not only about their own consumption but also the structure of the other person's private demands. Such preferences are usually termed 'altruistic'. Alternatively we could assume that each person has an individualistic felicity function de..ned over public goods and the individual's private consumption, $\hat{A}^{\prime}{ }^{\prime} q^{\prime} ; Q$, and that preferences are de. ned $\alpha_{\downarrow}$ ver the levels of these felicity functions. Thus $u^{\prime}=a I^{\prime} \dot{A}^{A}{ }^{\prime} q^{A} ; Q^{Y} ; \dot{A}^{B}{ }^{1} q^{B} ; Q^{Q C} ;$ following Becker we refer to such preferences as 'caring'. In this case person A only cares about $B$ 's private consumption insofar as it gives him pleasure. Finally we have the case of 'egotistic' preferences in which each individual cares only about their own individual felicity function: $u^{A}=\dot{A}^{A}{ }^{A} q^{A} ; Q$ and similarly for $B$. Of course, we can also have hybrids. For example, Becker's presentation of the R otten K id Theorem implicitly has one caring person and one egotistic person; we shall return to this below.

\subsection{Modelling the decision process.}

Having de..ned the constraints the household faces and the preferences of the two people we have to model how they resolve dixerences if the two people have dixerent ordinal preferences; that is, if $u^{A} \in F\left(u^{B}\right)$ for some strictly increasing $F(:)$. There are three broad options: a bargaining model, a model which assumes only ed ciency (the 'collective' model) or a non-cooperative model. If we assume that there is enough structure on the bargaining model to give Pareto ed cient outcomes (or even use a Nash assumption) then the former of the three cases is a special case of the second. In the general modelling of interactions between agents, each approach has it attractions and drawbacks. In the speci..c context considered here two elements seem particularly relevant. First, the household may be considered one of the pre-eminent examples of a repeated game with a fairly stable environment. Second, the two agents can safely be assumed to know each 
other's preferences (at least after a few years) ${ }^{3}$. Together these make the use of non-cooperative models that have outcomes that are not Pareto ec cient relatively unattractive. After all, if agents know each other and interact very often, why should they leave potential Pareto improvements unexploited?

Conversely, the two features mentioned make the collective model a very attractive modelling option. Additionally, the collective model leads to a surprising number of restrictions on observable outcomes (see Chiappori (1988) and (1992), Bourguignon, Browning, Chiappori and Lechene (1994), Bourguignon, Browning, Chiappori (1996) and Browning and Chiappori (1998)). The ..nal point in favour of the collective model is that we can identify a good deal of 'who gets what' within the household and how this changes as we change 'distribution factors' $^{\prime 4}$ (see Chiappori (1992) and B rowning, Bourguignon, Chiappori and Lechene (1994)). Distribution factors are variables which do not impact directly on tastes but that do axect the intra-household allocation decision (and hence household demands). Potential examples include the relative incomes of household members; divorce laws; social attitudes to the roles of men and women and the outside options of the digerent members. The drawback of the collective model is that it gives no hint of the process whereby members of a household might achieve a Pareto ec cient outcome nor where on the utility possibility frontier the household will be located. M ore importantly, it gives no guidance as to what variables should appear in the set of distribution factors. For example, some authors use relative incomes or relative earnings or relative non-labour incomes. Suppose, however, that it is relative potential wages that matter; that is, power within the household is determined not by actual market outcomes but by what the dixerent agents can threaten to do. Although the potential wage is correlated with earnings it obviously dixers for those who choose not to participate in the observation period. To derive more speci..c predictions, we need more structure; typically this will take the form of assuming a speci..c bargaining model.

If we move to a structured bargaining model then we must specify breakdown points and outside options which considerably complicates the theoretical analysis and also makes greater data demands. A number of breakdown points have been suggested in the literature. These range from divorce (see M cE Iroy and Horney (1981) and M anser and Brown (1980)) to each person reverting to traditional roles in the event of no agreement (see L undberg and Pollak (1992). For the bargaining

\footnotetext{
${ }^{3}$ T he availability of unobserved consumption - for example, taking leisure on a job - weakens this argument.

${ }^{4}$ M CE Iroy (1990) uses the term 'extra-household environmental parameters'.
} 
model in this paper, we consider one speci..c alternative, namely that the breakdown point for the bargaining game is a non-cooperative voluntary contributions game; this is presented below. This approach can be justi..ed by an appeal to each period being one of a number in a repeated game in which the non-cooperative outcome is used as a disciplining device.

To bring out the implications of the various models, we shall only consider the exects on the household demands for one private good and one public good (but we allow that there are many other public and private goods). In doing this we hold total expenditure and all other infuences on preferences constant. For expositional convenience, we assume that person A prefers the two goods we consider more than $B$ in the following sense. If we use A's utility function to determine household demands ( $A$ is a dictator) then the demand for these two goods is higher (and the demand for some other goods is lower) than if we use B 's utility function. In the following exposition we shall only present informal derivations; formal statements of propositions and proofs can be found in A ppendix B.

\subsection{A cooperative model.}

The ..rst case we consider is the collective model which assumes only that any intra-household allocation is ec cient. Formally, $\hat{q}^{A} ; \hat{q}^{B} ; \hat{Q}$ is ec cient if there is no other allocation that satis. es the same budget constraint that makes one person strictly better ox without making the other one worse ox. This is equivalent to household demands being rationalised by the household utility function:

$$
V\left(q ; Q^{\prime 1}\right)=\max _{q^{A} ; q^{B}}{ }^{\circledR} \dot{A}^{A}{ }^{i} q^{A} ; q^{B} ; Q^{\Phi}+\left(1 i^{1}\right) \dot{A}^{B}{ }^{i} q^{A} ; q^{B} ; Q^{\Phi} j q^{A}+q^{B}=q^{\underline{a}}
$$

This household utility function resembles the conventional utility function except that it allows for the infuence of the weight on the individuals' utility functions. If the weighting factor ${ }^{1}$ is a constant then this is simply the unitary model. Generally, however, the weight will depend on various (distribution) factors that refect the 'power' of the respective partners. In all that follows, we shall concentrate on the share of earnings of person $A$; that is,

$$
1 / 2=\frac{Y_{A}}{Y_{A}+Y_{B}}
$$

where $Y_{1}$ is the earnings of person I. For the collective model we shall assume that the weighting function ${ }^{1}$ is a strictly increasing function of $1 / 2$ T here is no explicit 
prior non-cooperative game that justi..es this assumption; rather it is implicitly based on a bargaining model in which a higher share of household earnings is rełected in a more favourable breakdown point ${ }^{5}$. We shall discuss the possible endogeneity of the earnings share in the empirical section.

The ..rst model (model 1) we consider is that in which preferences are egotistic; in this case the demand for both private and public goods is increasing in $1 / 2$ given the assumption that A prefers these two goods. For convenience, we have taken demands to be linear; see the top panels of ..gure 1. If we introduce caring (model 2) then we have that for extreme values of the earnings share the high income person is exectively making transfers to the low income person and demands are locally independent of the distribution of earnings. This is one version of Becker's 'Rotten Kid Theorem' so we refer to the intervals at the ends of the earnings distribution as the 'Becker' region. The bottom panels of ..gure 1 give an illustration of the predictions of the caring collective model. Note that the Becker regions are the same for all goods $([0 ; 0: 25]$ and $[0: 5 ; 1]$ in the case illustrated).

\subsection{A non-cooperative model.}

The non-cooperative model we consider is one in which each person makes voluntary contributions to the public good and their own private good from their own earnings (see Ulph (1988), Woolley (1993) and Rasheed (1996)). It is assumed that there is no other income (or that other income is distributed proportionately to earnings). We consider ..rst the egotistic case (model 3). If B has all the earnings $(1 / 2=0)$ then the household buys the amount of public and private goods that maximise his utility function subject to purchases equalling his earnings. Note that at this point the household allocations are ec cient since we cannot re-arrange them, keeping total expenditure constant, without making B worse ox. If, now, a small amount of the earnings of person $B$ are transferred to person $A$ then $B$ reduces his expenditure on all private goods (assuming normality) and also reduces his contribution to the public good. However, A does not contribute anything to the public good but rather concentrates her expenditures on her own private goods. Thus the contribution to all public goods actually falls even though $A$ prefers the public good relative to $B$. This is a seemingly paradoxical result and lends itself well to testing. Note that the new allocations are now inec cient since

\footnotetext{
${ }^{5}$ This lack of an explicit model is a weakness. Suppose, for example, that the weight ${ }^{1}$ depends on relative earnings and some other factor refecting $A$ 's household 'power'. If the latter increases then $A$ may decrease her earnings without ${ }^{1}$ decreasing.
} 

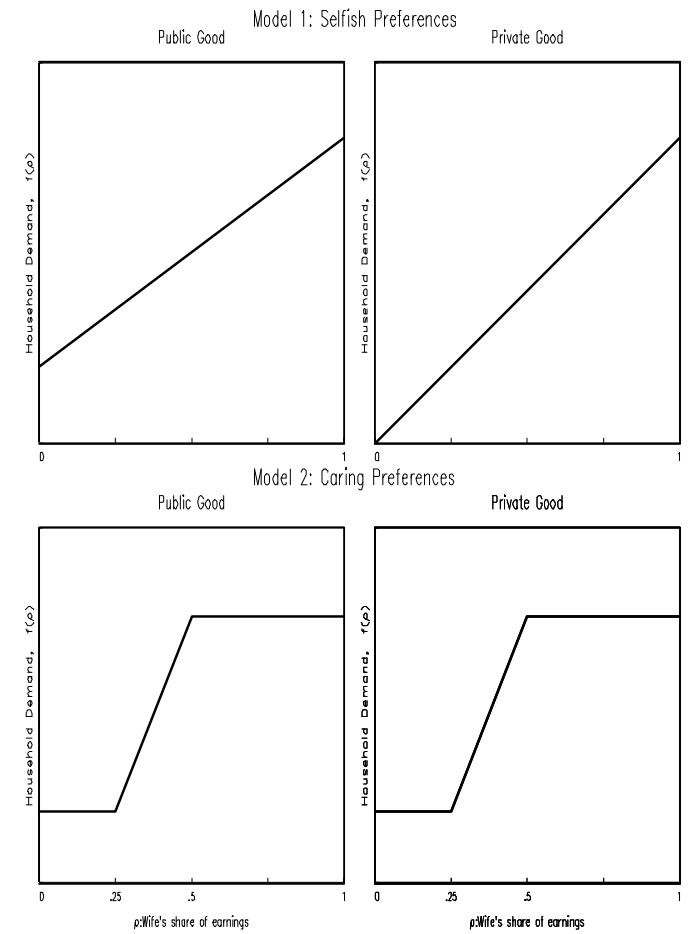

Figure 1: Cooperative Model Predictions 

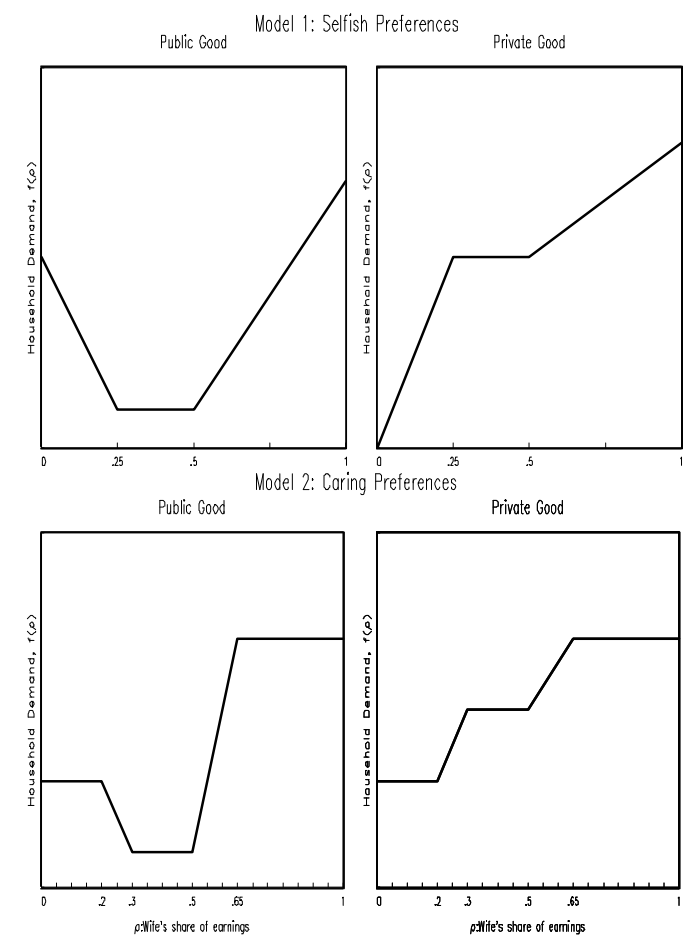

Figure 2: Non Cooperative Model Predictions

it would be possible to make both agents better ox by increasing their contributions to the public good; this is the standard ined ciency result for a voluntary contributions game with public goods.

As more earnings are transferred to A, at some point she starts contributing to the public good. If $B$ is still contributing to the public good at that point then we have the surprising and remarkable result due to Warr (1983) (see also Bergstrom, Blume and Varian (1986) and Bernheim (1986)). This result states that if a group of agents are all voluntarily contributing to a public good then small re-distributions of income will not lead to any changes in the allocation to any public or private goods. In the context here, this means that we have a 
central region for the distribution of earnings in which household demands are independent of the distribution of earnings; we term this the Warr region. As we continue to increase A's share of earnings, at some point B stops contributing to any public good and at that point any further transfer to A will lead to rising contributions to all public goods and any private goods she prefers more than B. The set of predictions is given in the top panels of F igure $2^{6}$. The Warr interval in this illustration is $(0: 25 ; 0: 5)$.

One example of this is if there are children in the household and both parents care for the children. Suppose they agree on the utility function of the children (even though they may give that utility level dixerent weights in their own individual welfare functions). Then goods that are bought exclusively for the child (for example, children's clothing) are a public good. If A cares more about the children than does $B$ then more will be spent on children's clothing if $A$ has all the earnings than would be the case if $B$ had all the earnings. If, however, we start from $B$ having all the earnings and then we make a small transfer to $A$ (so that total earnings are held constant) then she will decide to spend this on private goods for herself (her own clothing, for example) rather than on any public goods, including children's clothing. Thus such a transfer may lead to an increase in expenditures on women's clothing and a decrease for children's clothing since at the same time B will cut back his spending on children. Thus children are actually worse oven though the parent who cares more for them has a higher relative income.

If we now introduce caring between $A$ and $B$ (model 4) then we once again have $\ddagger$ at Becker regions at either end of the earnings distribution; see the bottom panels of Figure 2. This non-cooperative context is, actually, the one in which Becker introduced his neutrality result. Note that the motivation for the $\ddagger$ at portions in the middle and the two at the extreme are very dixerent. In the latter one person is acting as a benevolent dictator and outcomes are et cient whilst in the central region each person is acting sel..shly and outcomes are ineф cient. Note, once again, the coincidence of 'join' points across goods; that is, all demands start and stop being $\neq$ at at the same values of $1 / 2(f 0: 2 ; 0: 3 ; 0: 5 ; 0: 65 \mathrm{~g}$ in this illustration).

\footnotetext{
${ }^{6}$ If B stops contributing to all public goods before A starts then the $\ddagger$ at 'Warr' segment simply disappears.
} 


\subsection{A bargaining model with a non-cooperative breakdown point.}

As we emphasised in our discussion of the decision process earlier in this section, we do not ..nd inec cient outcomes very appealing in the household context. In this sub-section we consider a bargaining model which has a non-cooperative outcome as its breakdown point. This follows Lundberg and Pollak (1993) but we take a dixerent non-cooperative game than they did. Lundberg and Pollak consider a 'traditional spheres' game in which there are two public goods but each person can only contribute to one of them. Here we take the non-cooperative game of the previous sub-section as the breakdown point; this seems to us the more natural starting point.

Rasheed (1996) shows that the one shot bargaining game that results from a traditional Nash bargaining game is a sub-game perfect equilibrium of a repeated game with full information in which agents play the one shot game over and over again. Thus the bargaining model considered here is of considerable interest as being the only bargaining game in this context that formally captures the twin features that agents interact regularly and know each other well.

The question is: what properties does the bargaining outcome inherit from the non-cooperative game? For the egotistic case (model 5), Rasheed (1996) shows that the $\ddagger$ at 'Warr' portion for public and private goods appears for the bargaining outcome. This follows since in the Warr interval the breakdown point is locally independent of the distribution of earnings and hence the ..nal bargained outcome must also be independent. However, since the bargaining outcome is ed cient, it cannot be the case that the non-monotonicity in the earnings share is also inherited. Instead, starting from A having no earnings, as her share of earnings increases so does her bargaining position and hence the household ends up buying more of the public goods she prefers. Thus the public good and private goods are both non-decreasing; see the top panels of ..gure 3. As can be seen, the predictions for the two types of goods are the same; for goods A prefers we have a strictly increasing segment followed by a łat portion and then another strictly increasing segment. If we now introduce caring (model 6) then this simply adds Becker regions at the ends of the distribution see the bottom panel on ..gure 3.

In this section we have derived predictions for demands for public and private goods under three dixerent models for the determination of budget allocations. We have also shown that caring introduces $\ddagger$ at regions at the extremes of the income distribution. We turn now to testing between these various predictions. 

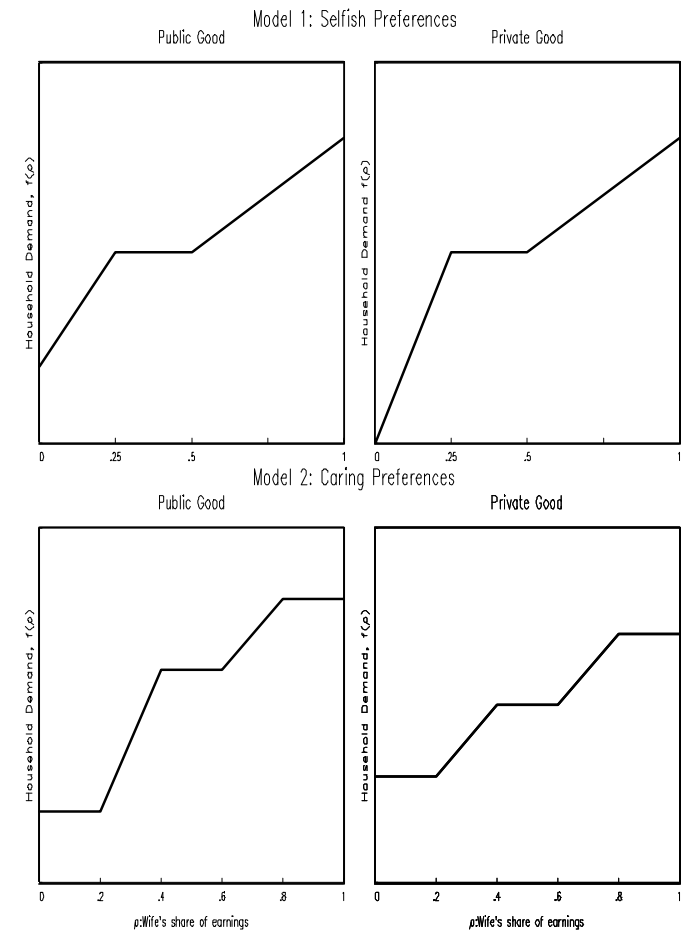

Figure 3: B argaining Model Predictions 


\section{Empirical results.}

\subsection{Data.}

The data are taken from the Canadian Family Expenditure Survey (FAMEX) for sampled years between 1969 to 1992. Here we give only a brief account of sample selection and data preparation; full details and a data description can be found in Appendix C. We shall consider only households that are headed by a married couple and in which both the husband and wife are in full-year full-time employment. We also select on there being at least one child aged less than 17 in the household and no other members aged 17 or over. The selection on a child being present is because we want to examine expenditures on children's clothing. The exclusion of households with adult children present is because the two decision maker framework may not be appropriate if there are more than two adults. We excluded households with no expenditure on food at home, household operations and the three clothing categories but not those with zero alcohol and tobacco. We excluded households with high budget shares for any good. Finally we found that the model was unstable for very low values of the wife's share of earnings so we exclude households in which this share is less than ...ve percent. After all these selections we are left with 2029 households in our sample. We account for relative price exects and a variety of demographic factors that are usually thought to modify preferences; these include age, the number and ages of children, region of residence and education; a full listing is given in Table A 1 . F inally we note that in constructing budget shares we used the ratio of individual good expenditures to total non-durable expenditure.

Since the models' predictions consist in restrictions on the relationship between the distribution of income within the household and demand, we start by the former: see ..gure 4.As we might expect the distribution of the wife's share of household income is concentrated below one half with quantiles of 0:33; 0:40 and $0: 48$. The proportion of women with earnings higher than their partner is $18: 2 \%$ with less than two percent earning more than twice their husband (a share of $0: 66)$. Consequently we must not expect too much precision in testing for exects at the high end of the distribution.

\subsection{Empirical methods.}

In the theory section we developed three models: a collective model; a noncooperative model and a bargaining model with the non-cooperative outcome 


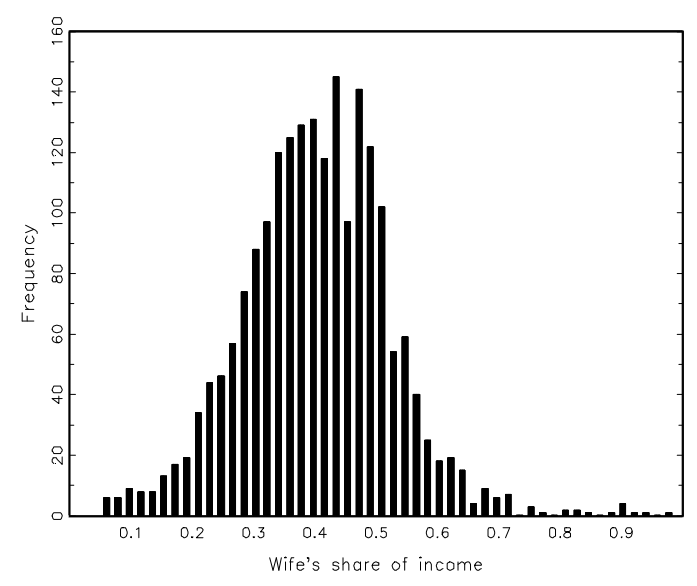

Figure 4: Distribution of wife's share of income

as a breakdown point. For each of these we have predictions for the demands for public and private goods with and without caring. Our approach to testing be tween these models will be to identify ex ante some public and some private goods and then to test for the various predictions. For public goods we take 'children's clothing' and 'household operations' (which includes water, fuel, electricity and telephone but not child care expenses). For private goods we consider 'food at home'; 'vices' (that is, alcohol and tobacco); 'men's clothing' and 'women's clothing'. Although this is not exhaustive of non-durables and services we consider the classi...cation of other goods (such as 'food outside the home' and 'entertainment') as private or public too conjectural to make it feasible to use them. The six goods we model account for about one half of total expenditures on non-durables.

We assume that all the households have the same decision process and that the population is homogenous enough in terms of level of total income so that the join points are the same for everyone. ${ }^{7}$ Let $1 / 2$ be the share of income of the wife. We take the unrestricted form of the models to be:

\footnotetext{
${ }^{7}$ We modelled and estimated some speci..cations with heterogeneity in the join points. These never gave a signi..cantly better ..t than the corresponding models with homogeneity reported below.
} 


$$
E\left[!_{i} j X ;{ }^{1 / A}=X^{-}+g\left({ }^{1} A\right.\right.
$$

where $!_{i}$ is the budget shares for good $i, X$ is the matrix of explanatory variables other than $1 / 2$ and $g$ is a function describing the relationship between the share of income of the wife and the response $\mathrm{w}_{\mathrm{i}}{ }^{8}$ In equation (3) the matrix $X$ contains log prices, demographics and the logarithm of total expenditure $(x)$ and its square.

There are several ways suggested in the literature for estimating a partially linear structure such as (3) (see for example, Robinson (1988) and Härdle (1990)). These are not easily adapted to the GM M system framework we use here to take account of the endogeneity of total expenditure. Instead we adopt a ‡exible procedure that ..rst involves estimating an unrestricted form of equation (3) using GMM applied to $X$ and splines of $1 / 2$ Speci..cally we divide the sample sorted by $1 / 2$ into 20 equally sized groups (with 19 join points) and construct 20 variables that give a piecewise linear and continuous function of the wife's share. We then include these variables on the right hand side of our equation (along with the $X$ variables) and in the set of instruments. We instrument the total expenditure variables with log net income and its square. Thus we have a just identi..ed, linear unrestricted system with $\operatorname{dim}(X)+20$ right hand side variables for each equation. This can be estimated using GM M in the usual way; the weighting matrix from this unrestricted model is used in all subsequent testing of restricted models. We have 120 share coed cients in the unrestricted model; with the sample size to hand this obviously leads to very imprecise estimates but that does not matter since we are only using the unrestricted model for testing heavily restricted variants.

To test for the various models developed in the theory section, we use a minimum- $\hat{A}^{2}$ procedure that restricts sets of coed cients on the unrestricted $1 / 2$ splines to be the same. To illustrate, consider testing for a one join model (with the same join point for all 6 goods) with a $\ddagger$ at segment and then a slope. This corresponds to a collective model in which husbands care for their wives (so that the initial $\ddagger$ at segment is a Becker region) but wives do not care for husbands. There are only 7 share coed cients for this model: the single join point and the 6 slope coet cients. If we ..x the join point at one of the 19 join points from the unrestricted system then we have a model that is nested in the unrestricted

\footnotetext{
${ }^{8}$ We made attempts to allow for the possible endogeneity of the income share $1 / 2 b y$ running speci..cations with this share instrumented. As instruments we tried crossed region and year dummies and also measures of relative wages for full-time employed men and women in the region-year. In no case could we reject exogeneity. On the other hand, the instruments are relatively weak and this test can hardly be considered conclusive.
} 
model. For example, if we take the fourth join point then our $\ddagger$ at-slope structure implies that the coed cients on the ..rst four coed cients in each equation are zero and the last sixteen coec cients equal within each equation. This gives $24+90 \mathrm{i} 1$ restrictions (the i 1 is to allow for the join point being estimated). The $\hat{A}^{2}$ test statistic for these restrictions is readily calculated using minimum- $\hat{A}^{2}$ methods. To ..nd the optimal join point we grid search over the 19 join points from the unrestricted model and take the value that gives the minimum of the 19 statistics as the optimal value. This approach has the disadvantage that we have not treated the income share as a continuous variable. On the other hand, this procedure is feasible and reasonably fast and is likely to give results that are close to the 'correct' since we have taken a relatively ..ne grid for the unrestricted model. ${ }^{9}$

\subsection{Empirical results.}

The ..rst step is to estimate the unrestricted model. Then we need to test the restrictions from the theory section. Even with the minimum- $\hat{A}^{2}$ grid search method outlined above, estimation of models with more than two join points is very cumbersome. Consequently we estimated a relatively small number of re stricted models. We estimate all three one join models (' $¥$ at-slope', 'slope $\neq$ at' and 'slope-slope') and three two join models (' $¥$ at-slope- $\neq a t '$, 'slope- $\ddagger$ at-slope' and 'slope-slope-slope') From these we choose a statistically preferred model and then test whether particular variants of this model give an improvement. The variants we use for this are two three join models with 'slope- $\neq$ at-slope- $\neq$ at' and ' $¥$ at-slope-łat-slope'. Table 1 presents the results for these models and the unitary and collective models. The criterion values given in the Table provide tests of the given models against the unrestricted model. The dixerences in the $\hat{A}^{2}$ criteria between nested models give the test statistics for the restriction. For example, comparing the unitary and the collective (with no caring) model we see that the 6 restrictions to go from the latter to the former have a $\hat{A}^{2}$ statistic of 29: 4 which has a probability of less than 0:01\% under the null that the unitary model is correct. This is the usual rejection of income pooling. To conduct our testing, we begin with the least restricted two join model which has 20 parameters. As can be seen from the Table, neither of the two join models with one or two $\ddagger$ at segments can be rejected against this more general model $\left(\hat{A}^{2}(6)=7: 1\right.$ and $\hat{A}^{2}(12)=11: 7$ respectively). The slope $\neq$ at-slope model can be simpli..ed to the one join slope-slope model $\left(\hat{A}^{2}(1)=0: 6\right)$. This latter model, however, is in turn

\footnotetext{
${ }^{9}$ Limited experiments with ..ner grids gave similar qualitative results.
} 
rejected against the slope $\neq$ at model (a $\hat{A}^{2}(6)$ of 8 ). Thus following this branch we conclude that the slope- $\neq$ at is preferred. On the other hand, all of the simpler models are rejected against the $\neq$ at-slope $\neq$ at model. The restrictions of the $\ddagger$ at-slope- $\ddagger$ at model to the slope $\neq$ at and $\ddagger$ at-slope models have $\hat{A}^{2}(1)$ statistics of 4 and 10:2 respectively. Importantly, the collective model with no caring is also decisively rejected $\left(\hat{A}^{2}(2)=10: 2\right.$ with a probability of less than $\left.0: 5 \%\right)$. We conclude that the $\ddagger$ at-slope- $\ddagger$ at model is the statistically preferred model.

Our preferred $\ddagger$ at-slope $\neq$ at model has a $\hat{A}^{2}(107)$ statistic of $127: 8$ so that the preferred model is not rejected against the very unstructured general model. It may be, however, that some model with more than two joins is preferred to the $\ddagger$ at-slope- $\neq$ at model. As stated above it is very onerous to grid search over more than two join points so we consider only two three join point alternatives. These

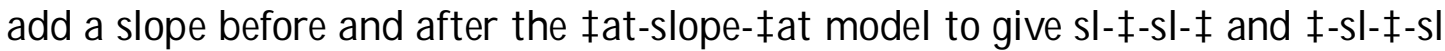
respectively. Referring again to Table 1 we see that both of these are not rejected against the ¥at-slope-łat two join model ( $\hat{A}^{2}(7)$ values of $4: 6$ and 8:4). Thus our preferred model is also not rejected against less restricted, parsimonious variants.

The preferred model suggests that both husbands and wives display sharing. The join points given in Table 1 (0:21 and 0:43) are at the 10th and 60th percentiles of the income share distribution. Thus about a half of the households have relative incomes such that a re-distribution of income would lead to a change in budget allocations. In Tables D 1 to D 6 in A ppendix D we present the parameter estimates for the $\ddagger$ at-slope $\ddagger$ at model. In Table 2 we present the coec cient estimates for the collective models with and without sharing and in ..gures 2 to 7 we present the predictions for the budget shares conditional on the sharing variable for the collective model with and without sharing. The ..rst thing to note is that for those goods for which we had a prior on the slopes, this prior is con..rmed. Thus women and children's clothing is increasing in the wife's share and men's clothing and vices are decreasing. We also ..nd that food at home and services are decreasing in the wife's share.

A second feature of the parameter estimates of both models is that they indicate fairly substantial changes for some allocations consequent on a re-distribution of within household income. To illustrate, in columns 1 and 2 of Table 3 we present the budget share estimates for values of $1 / 2$ equal to $0: 25$ and $0: 75$. In column three we give the dixerence proportional to the mean budget share. As can be seen, for our preferred model the budget shares for women's clothing and children's clothing rise by about $11 \%$ and $8 \%$ respectively whilst the shares for men's clothing and vices fall by about $6 \%$ and $5 \%$ respectively. 


\section{Conclusions.}

We have presented a theoretical analysis of the predictions of dixerent models of intra-household decision processes on budget allocations. In particular, we derived the restrictions on the relationship between demands and the wife's share of income for four dixerent models. We have shown that the dixerent models give rise to radically dixerent qualitative predictions which lend themselves well to testing. In the empirical section we used Canadian family expenditure survey data to test between the alternatives. Our main conclusions are:

2 We do not ..nd any evidence for a $\ddagger$ at region surrounded by slope regions that is, an interior region of (Warr) pooling. We interpret this as evidence against both non-cooperative behaviour and a bargaining game with noncooperative behaviour as a breakdown point.

2 We ..nd robust evidence of caring by both husbands and wives. Speci..cally, we ...nd that when the distribution of income is skewed the high income partner behaves as though he or she is a dictator who cares for the other partner. This (local) income pooling is the behaviour posited by Becker in his Rotten Kid theorem.

2 Although we ..nd evidence for caring we also ..nd that for about half of our sample the distribution of household income is such that income pooling fails. In this central region a re-distribution of household income would lead to a change in the budget allocations.

2 We ..nd that households in which the wife has a high income share spend relatively more on women's and children's clothing (increases of $11 \%$ and $8 \%$ respectively for a change in the share from 0:25 to 0:75) and relatively less on men's clothing and alcohol and tobacco (falls of $6 \%$ and $5 \%$ respectively).

The major reservations we have about these conclusions are that we have treated the income share as exogenous and we have assumed that everyone has the same decision process and the same parameters for that process. As we have mentioned above, we tried to take account of these two shortcomings but there was no evidence that either was important. On the other hand, we have a relatively small sample and the data are rather noisy so we suspect that the negative ..ndings on endogeneity and heterogeneity may be more due to a lack of power in our tests. E ven allowing for this, however, it is clear that the simple collective model without 
caring is rejected and that more structured models of intra-household behaviour are needed. In particular, it seems that we should allow that husband and wife care for each other, although not completely.

\section{A. Tables}

\begin{tabular}{|c|c|c|c|c|c|}
\hline Table 1: Test results. & & & & & \\
\hline Model & J oin 1 & J oin2 & J oin 3 & $\begin{array}{l}\text { Number of } 1 / 2 \\
\text { parameters }\end{array}$ & Criterion \\
\hline Unitary & $i$ & $i$ & $i$ & 0 & $167: 4$ \\
\hline Collective (no caring) & $\overline{\mathrm{i}}$ & $\mathrm{i}$ & $\mathrm{i}$ & 6 & $138: 0$ \\
\hline Flat-slope & $0: 21$ & $i$ & $i$ & 7 & $138: 0$ \\
\hline Slope $\ddagger$ at & $0: 43$ & $\mathrm{i}$ & $\mathrm{i}$ & 7 & $131: 8$ \\
\hline Slope-slope & $0: 43$ & $\mathrm{i}$ & $\mathrm{i}$ & 13 & $123: 8$ \\
\hline Flat-slope $\neq$ at & $0: 21$ & $0: 43$ & $i$ & 8 & $127: 8$ \\
\hline Slope-‡at-slope & $0: 43$ & $0: 58$ & $\mathrm{i}$ & 14 & $123: 2$ \\
\hline Slope-slope-slope & $0: 33$ & $0: 34$ & $\mathrm{i}$ & 20 & $116: 1$ \\
\hline FI-s|-‡-s| & $0: 21$ & $0: 43$ & $0: 58$ & 15 & 119:4 \\
\hline Sl-‡-sl-‡ & $0: 43$ & $0: 51$ & $0: 54$ & 15 & $123: 2$ \\
\hline
\end{tabular}

\begin{tabular}{|l|l|l|}
\hline \multicolumn{3}{|c|}{ Table 2: Slope parameter estimates. } \\
\hline & No sharing & W ith sharing \\
\hline Food at home & i $2: 17$ & i $3: 89$ \\
& {$[2: 2]$} & {$[2: 3]$} \\
\hline Services & i $0: 43$ & i $2: 52$ \\
& {$[0: 6]$} & {$[2: 0]$} \\
\hline Women's clothing & $1: 54$ & $3: 31$ \\
& {$[3: 1]$} & {$[3: 7]$} \\
\hline Men's clothing & i $0: 31$ & i $1: 34$ \\
& {$[0: 8]$} & {$[2: 0]$} \\
\hline Children's clothing & $1: 01$ & $1: 54$ \\
& {$[2: 8]$} & {$[2: 6]$} \\
\hline Vices & i $1: 45$ & i $1: 42$ \\
& {$[1: 8]$} & {$[1: 0]$} \\
\hline \multicolumn{2}{|l}{ Values in [:] are absolute t-statistics } \\
\hline
\end{tabular}




\begin{tabular}{|c|c|c|c|c|}
\hline \multicolumn{5}{|c|}{ Table 3: Budget share predictions } \\
\hline & M odel & $1 / 2=0: 25$ & $1 / 2=0: 75$ & $\begin{array}{c}\text { Proportional } \\
\text { dixerence (\%) }\end{array}$ \\
\hline Food & No join & $21: 12$ & $20: 04$ & i $5: 0$ \\
& T wo join & $21: 51$ & $20: 80$ & i $3: 3$ \\
\hline Services & No join & $12: 88$ & $12: 66$ & i $1: 7$ \\
& T wo join & $12: 88$ & $12: 42$ & i $3: 5$ \\
\hline Women's clothing & No join & $5: 90$ & $6: 67$ & $+14: 0$ \\
& T wo join & $5: 65$ & $6: 25$ & $+10: 9$ \\
\hline M en's clothing & No join & $3: 76$ & $3: 60$ & i $4: 1$ \\
& T wo join & $3: 78$ & $3: 54$ & i $6: 3$ \\
\hline Children's clothing & No join & $3: 82$ & $4: 32$ & $+14: 1$ \\
& T wo join & $3: 63$ & $3: 91$ & $+7: 9$ \\
\hline \multicolumn{7}{|l|}{ Vices } & No join & $5: 17$ & $4: 46$ & i $13: 1$ \\
& T wo join & $5: 48$ & $5: 22$ & i $4: 7$ \\
\hline All budget share values multiplied by 100. \\
\hline The terms 'no join' and 'two join' refer to the collective model without \\
and with caring respectively.
\end{tabular}




\section{B. Theory appendix}

We use the same notation as before. Subscripts $A$ and $B$ refer to the two members of the household; $q^{i}$ represents the vector of private goods consumed by individual $\mathrm{i}$ and $\mathrm{Q}$ the vector of public goods consumed in the household. B oth private and public goods are normal. Preferences can be sel..sh or caring. The household budget constraint is:

$$
e^{0^{i}} q^{A}+q^{B}{ }^{\Phi}+e^{Q} Q=Y_{A}+Y_{B}=Y
$$

where $Y_{i}$ is individual $i$ 's income and $e$ is the approriately sized vector of ones. For expositional convenience, we assume savings away. We also assume that the level of household income is su $\$$ cient to ensure positive expenditure on the public good.

\section{B.1. N on Cooperative model}

Household decisions are described by a Nash equilibrium with voluntary contributions to the public goods. The properties of this game are well known. In particular, under the assumption of strict convexity of preferences, an equilibrium exists. Under the assumption that both the private and the public goods are normal, this equilibrium is unique. This doesn't seem to be too strong a requirement, especially with broad grouping of goods such as is the case here. Formal proofs can be found in Bergstrom, Blume and Varian (1986). Finally, if both partners have some income and if at least one person is contributing to the public good, the outcome of this game is ined cient. This is due to the fact that agents do not account for the externality induced by the public good, that is, it is due both to the assumption of sel..sh preferences and to the absence of coordination between household members in this game. Note that the outcome is ef cient when all the income goes to one member.

We .rst consider the case where both agents' preferences are sel..sh; then the case where one of the agents' preferences are caring while the other's are sel..sh; and ..nally the case where both agents' preferences are caring. We assume that there is one private good and one public good.

\section{B.1.1. Both members sel..sh}

Each individual maximises utility $U_{i}=v_{i}\left(q^{i} ; Q\right)$, taking the choices of individual $j$ as given, and choices are subject to the individual's budget constraint. Each 
individual contributes an amount $g^{i}$ to the public good, so that $g^{i}+q^{i}=Y_{i} ; i=$ $A ; B$ and $Q=g^{A}+g^{B}$ : The results shown are also valid if $Q=f\left(g^{A}+g^{B}\right)$ , but not necessarily for the more general case where $Q=f\left(g^{A} ; g^{B}\right)$ : In other words, we consider only pure public goods. Transfers between household members are impossible in this setting which combines sel..sh preferences and independent decision making (given the choices of the other member).

The ...rst order conditions of this problem lead to:

$$
v_{i}^{q}, v_{i}^{Q} \text { for } i=A ; B \text {, }
$$

leading respectively to interior and corner solutions for each individual:

$$
\begin{array}{llll}
8 & v_{i}^{\mathrm{a}}=v_{i}^{Q} \quad \phi<Y_{i} \quad \phi>0 \\
: & v_{i}^{x}>v_{i}^{Q} \quad \phi=Y_{i} \quad \phi=0
\end{array}
$$

We rule out the case where the marginal utility of the private good is strictly lower than that of the public good.

There are therefore 3 possibilities for the household: both members contribute to the public good, or either member ( $A$ or $B$ ) contributes while the other one doesn't (B or A).

Income Pooling Proposition 1: For this Nash equilibrium, if both individuals are contributing to the public good, there is income pooling.

Proof: If both individuals are contributing to the public good, individual B's $\overline{\text { problem }}$ can be written as:

$$
\max _{q^{B}} v_{B}\left(q^{B} ; Y_{A}+Y_{B} i q^{A} ; q^{B}\right)
$$

For an interior solution, and for small reallocations of income between $A$ and $B$, the problem, and hence its solution are unchanged.

For this property to hold, the reallocations of income have to be small enough so that the household stays at an interior solution; in other words, such that both household members continue to contribute to the public good. This result (with dimerent proofs) can be found in Warr(1983) and in Bergstrom, Blume and Varian (1986). 
If there is only one contributor to the public good, then reallocations of income between household members do have an exect on outcomes, i.e. on the structure of expenditure. Indeed, if B is not contributing, then:

$$
v_{B}\left(Y_{B} ; Y_{A} ; q^{A}\right), v_{B}\left(Y_{B} ; " ; Y_{A} ; q^{A}+"\right)
$$

Evolution of expenditure as a function of income shares Let the share of household income accruing to member $\mathrm{A}$ be denoted by:

$$
1 / 2=\frac{Y^{A}}{Y^{A}+Y^{B}}
$$

Let $1 / 2$ be the value of $1 / 2$ such that for smaller values of $A$ 's share of income, $B$ is the only contributor to the public good. Let $1 / 2$ be the value of $1 / 2$ such that for larger values of A 's share of income, $A$ is the only contributor to the public good. For values of $1 / 2$ between $1 / 2$ and $1 / 2$, both individuals contribute to the public good, and we have shown that there is income pooling. The evolution of the quantities demanded of public and private goods when the share of income varies are directly

\begin{tabular}{|c|c|c|c|}
\hline $\begin{array}{l}\text { Contrib- } \\
\text { utors to Q: }\end{array}$ & $\begin{array}{l}\text { R ange } \\
\text { of } 1 / 2\end{array}$ & $\begin{array}{l}\text { Evolution of } \\
\text { expenditure }\end{array}$ & $\begin{array}{l}\text { Indirect } \\
\text { Utility }\end{array}$ \\
\hline B & {$[0 ; 1 / 2]$} & 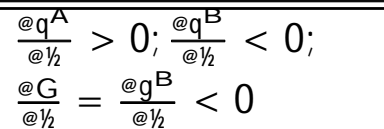 & $\begin{array}{c}v_{A}(1 / A ;(1 ; 1 / A Y) \\
V_{B}\left(\left(1 ;{ }^{1 / A Y} ;(1 ; 1 / A Y)\right.\right.\end{array}$ \\
\hline$A$ and $B$ & {$[1 / 2 ; 1 / 2]$} & 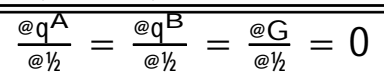 & $\mathrm{v}_{\mathrm{A}}(\mathrm{Y} ; \mathrm{Y}) ; \mathrm{v}_{\mathrm{B}}(\mathrm{Y} ; \mathrm{Y})$ \\
\hline $\bar{A}$ & {$\left[\frac{11 / 2 ; 1]}{2}\right.$} & 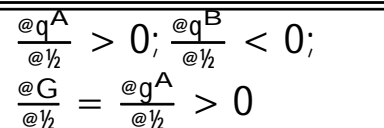 & $\begin{array}{r}v_{A}(1 / A ; 1 / Y) \\
V_{B}\left(\left(1 ; 1 / Y Y_{1}^{1} / Y\right)\right.\end{array}$ \\
\hline
\end{tabular}
deduced from the assumption that all goods are normal.

These results give rise to the picture presented in the text. 


\section{B.1.2. One caring individual}

A ssume, for instance, that $A$ is sel..sh and $B$ is caring. Preferences can be written:

$$
\mathrm{U}_{\mathrm{A}}=\mathrm{v}_{\mathrm{A}}\left(\mathrm{q}^{\mathrm{A}} ; \mathrm{Q}\right) \text { and } \mathrm{U}_{\mathrm{B}}=\mathrm{F}\left(\mathrm{v}_{\mathrm{A}}\left(\mathrm{q}^{\mathrm{A}} ; \mathrm{Q}\right) ; \mathrm{v}_{\mathrm{B}}\left(\mathrm{q}^{\mathrm{B}} ; \mathrm{Q}\right)\right)
$$

The game remains the same as in the previous case, save for the fact that the structure of the preferences opens the possibility of income transfers from the caring individual to the sel..sh individual. A 's choices are made subject to $q^{A}+g^{A}=Y_{A}+t$, where $t>0$ is the transfer made to $A$ by $B$. $B$ 's choices now include the amount transferred to $A$ and are made subject to $q^{B}+g^{B}+t=Y_{B}$.

The results in this case conform to the intuition conveyed by the form of the preferences. When the sel..sh individual is relatively poor, the caring individual will transfer money to him. As the share of household income held by the selfish individual increases, the transfers decrease up to a point where they become zero. Over part of the range with positive transfers, only the caring individual contributes to the public good. Then transfers cease, and then (or at the same point, depending on preferences), both individual start contributing to the public good. At the other extreme, when the sel..sh individual controls a large enough share of the income of the household, he becomes the only contributor to the household public good., and in this case also there is no transfer. Indeed, the transfer can only be positive, i.e. the sel..sh individual will never transfer to the caring individual.

For individual B, the ..rst order conditions of this problem lead to:

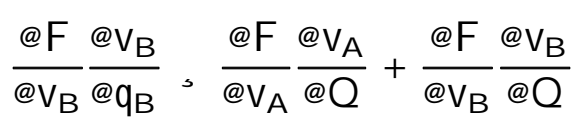

There are 3 cases, depending upon whether one or both individual contribute to the public good. We can substitute out for private good demands and write the utility of the caring individual in terms of incomes, transfers, and contributions as:

$$
U_{B}=F\left(v_{A}\left(Y_{A}+\varphi_{i} g_{A} ; g_{A}+g_{B}\right) ; v_{B}\left(Y_{B} ; \quad \varphi_{i} g_{B} ; g_{A}+g_{B}\right)\right)
$$

We will be using the expression of the partial derivative of individual $B$ 's utility with respect to the transfer to ..nd out when the transfer is positive. In all cases: 


$$
@ \mathrm{U}_{\mathrm{B}}=\mathrm{g} \mathrm{t}=\mathrm{F}_{1} \mathrm{v}_{\mathrm{A}}^{\mathrm{q}} ; \quad \mathrm{F}_{2} \mathrm{v}_{\mathrm{B}}^{\mathrm{q}}
$$

Case 1: Both individuals contribute to the public good. Using the fact that we are at an interior solution, we can rewrite $\mathrm{U}_{\mathrm{B}}=\mathrm{gl}_{\mathrm{t}}=\mathrm{i}_{\mathrm{F}} \mathrm{v}_{\mathrm{B}}^{\mathrm{G}}<0$ : T herefore, if both individuals are contributing to the public good, the transfers are zero.

Case 2: The sel..sh individual is the only contributor. In this case, $\mathfrak{d}_{\mathrm{B}}=\mathrm{at}<$ i $F_{2} v_{B}^{G}<0$; so that here as in the previous case the optimal level of transfers is zero.

Case 3: The caring individual is the only contributor to the household public good. Replacing in the expression of the partial derivative of $B$ 's utility with respect to the transfer, we get $@ \bigcup_{B}=@ t=F_{1}\left(v_{A}^{q} i V_{A}^{G}\right) ; F_{2} V_{B}^{G}$ : Both terms in this expression are positive. The expression can be either positive or negative. If $B$ values marginally more the disequilibrium for $A$ than his/ her own marginal satisfaction from the public good, transfers will be positive; otherwise transfers will be zero. The case of positive transfers which appears here is the case described by Becker (1981) as providing foundation for the unitary model of household behavior.

To summarize, if the transfers are positive, then we know that the individual transferring is also the only contributor to the public good. Note that this is not an equivalence: there can exist a range of the distribution over which the caring individual is the only contributor but doesn't transfer. If the transfers are zero, then either both are contributing or only one is.

I ncome Pooling If the transfers are positive, then household income is pooled. Indeed in this case, small reallocations of income between household members can be compensated by changes in the level of transfer. As the share of income of the poor individual increases, the transfer decreases, leaving all else unchanged. Income pooling can also emerge, as in the egotistic case, if both individuals contribute to the public good.

Evolution of expenditure as a function of income share Let $1 / 2$ and $1 / 2$ represent the same critical values for the income share of $A$ as in the previous case. We introduce another critical value for $1 / 2$ here: it is the value of the share of income of member $A$ below which transfers are positive. We have: 


\begin{tabular}{|c|c|c|c|}
\hline $\begin{array}{l}\text { Contributors } \\
\text { to Q: }\end{array}$ & $R$ ange of $1 / 2$ & Transfers & $\begin{array}{l}\text { Evolution of } \\
\text { Expenditure }\end{array}$ \\
\hline B & {$[0 ; 1 / 2]$} & $\overline{b>0}$ & 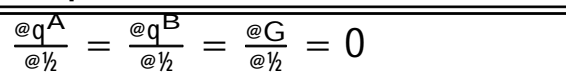 \\
\hline$B$ & {$[1 / 2 ; 1 / 2]$} & $b=0$ & 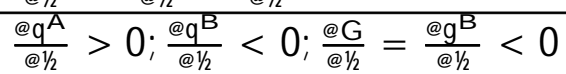 \\
\hline$A$ and $B$ & {$[1 / 2 ; 1 / 2]$} & $b=0$ & 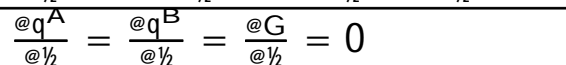 \\
\hline $\mathrm{A}$ & {$[1 / 2 ; 1]$} & $b=0$ & 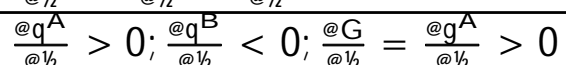 \\
\hline
\end{tabular}

\section{B.1.3. Both members caring}

Following the analysis in the previous paragraph, it is obvious that the assumption of mutual caring leads to a third range of values for the income share where household income is pooled.

Note that we have shown that income pooling can emerge as a local property of demand under 2 types of circumstances: 1) "à la Becker", essentially because of the caring hypothesis in a non cooperative context, 2) in the Warr region, because of the interdependency introduced by the presence of the public good in both members, when both are contributing to the public good.

\section{B.1.4. Multiple public goods}

The income pooling result holds over the range of the intra-household distribution where both household members jointly contribute to all the public goods (Bergstrom, Blume and Varian, 1986) and, with caring preferences, over a range of the intra-household distribution where resources are unequal.

\section{B.2. Bargaining model with non cooperative breakdown point}

We now consider the case where household decisions are obtained as solutions of a Nash bargaining game, in which the threat point is the solution of the non cooperative $\mathrm{N}$ ash equilibrium of the previous section. Under the standard assumptions on individual utility functions, the solution to a bargaining problem of this sort exists, is unique and eфc cient.

Preferences are assumed to be sel..sh for both individuals in the ..rst case, and then either sel..sh for one individual and caring for the other or caring for both household members. The question is: what properties does the solution of this cooperative game inherit from the non cooperative threat point. The results, 
presented here for the case with one private good and one public good generalise to the case of multiple public goods.

\section{B.2.1. Both members sel..sh}

Each individual's preferences are de..ned as previously on her/ his consumption of private goods and on the household public good, $U_{i}=v_{i}\left(q^{i} ; Q\right)$ : Choices are subject to the household budget constraint. The Nash bargaining problem can be written as:

$$
\begin{gathered}
\max _{q^{A} ; q^{B} ; Q}{ }^{f} v_{A}\left(q^{A} ; Q\right) i v_{A} \stackrel{a f}{f} v_{B}\left(q^{B} ; Q\right) i{ }^{\nabla_{B}}{ }^{\alpha} \\
\text { such that } q^{A}+q^{B}+Q=Y^{A}+Y^{B}=Y
\end{gathered}
$$

Income pooling The Warr region of income pooling is inherited by the Nash solution. To show this, rather than working from the Nash program as it is written just above, it is easier to start from the de..nition of the Nash solution as Nash had formulated it. The Nash solution is entirely de.ned by a Pareto frontier and a pair of threat points.

P roposition 2: The Nash solution inherits the Warr region of income pooling from the threat point.

Proof: Since the Pareto frontier depends only on household income, the Nash solution will depend on household income and whatever de.nes the threat point. Hence in the region where the threat point depends only on household income, so will the Nash solution, since it is unique. Similarly, in the region where the threat point depend upon the repartition of income, the Nash solution will depend upon the repartition of income between household members.

Evolution of expenditure as a function of the income share There re mains to examine what is the behavior of the expenditure on the public good outside the $[1 / 2 ; 1 / 2]$ interval. For this, we need an additional assumption on individual preferences: we assume that member $A$ relatively cares more for the public good than does member $B$ : O utside the Warr region, the threat point depends on the distribution of income, therefore so does the bargaining solution. However, as the share of income of individual A increases, so does that individual's bargaining power, so that the expenditure on $A$ 's private goods as well as on the public goods that $A$ cares for relatively more than $B$; does increase. 


\begin{tabular}{|c|c|c|}
\hline $\begin{array}{l}\text { Contributors } \\
\text { to Q: }\end{array}$ & $R$ ange of $1 / 2$ & $\begin{array}{l}\text { Evolution of } \\
\text { Expenditure }\end{array}$ \\
\hline $\mathrm{B}$ or $\mathrm{A}$ & {$[0 ; 1 / 2][[1 / 2 ; 1]$} & 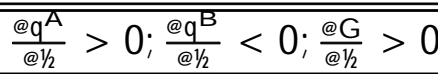 \\
\hline$A$ and $B$ & {$[1 / 2 ; 1 / 2]$} & 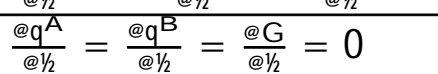 \\
\hline
\end{tabular}

B.2.2. One caring individual or both members caring

The assumption of caring preferences by one or both members adds a region of income pooling when intra-household resources are unequally distributed, "a la Becker". 


\section{Data description.}

The Canadian FAMEX is a multi-staged strati..ed clustered survey that collects information on annual expenditures, incomes, labour supply and demographics for individual households. The survey is run in the Spring after the survey year (that is, the information for 1978 was collected in Spring 1979). The survey years are 1969, 1974, 1978, 1982,1984, 1986, 1990 and 1992. All of the information is collected by interview so that the expenditure and income data are subject to recall bias. Although this may give rise to problems, the FAMEX surveying method has the great advantage that information on annual expenditures is collected. Thus the FAMEX has much less problem with infrequency bias than do surveys based on short diaries. It is also the case that since the survey year coincides with the tax year (J anuary to December) the income information is thought to be unusually reliable since it is collected at about the time that Canadians are ..ling their (individual) tax returns. These are often explicitly referenced by the enumerators.

Prices are taken from Statistics Canada. When composite commodities are created, the new composite commodity price is the weighted geometric mean of the component prices with budget shares averaged across our sample for weights.

Table $\mathrm{C} 1$ gives the sample selection path followed; the principal selection is on both husband and wife being in full-time employment and their being at least one child present.

\begin{tabular}{|c|c|}
\hline \multicolumn{2}{|c|}{ Table C 1: Sample selection } \\
\hline \hline & Numbers in sample \\
\hline \hline Couples with children & $17 ; 848$ \\
\hline Both in full-time employment & $2 ; 815$ \\
\hline Both partners have positive incomes & $2 ; 799$ \\
\hline No adult children & $2 ; 298$ \\
\hline Drop zero and high budget shares & $2 ; 034$ \\
\hline W ife's share $>0: 05$ & $2 ; 029$ \\
\hline
\end{tabular}

Tables C 2 and C 3 present sample means and other statistics for all of the variables used in the analysis (except for the prices). 


\begin{tabular}{|c|c|c|}
\hline \multicolumn{3}{|c|}{ Table C2: BUDGET SHARES AND INCOMES. } \\
\hline \hline BUDGET SHARES & Mean & Standard deviation \\
\hline \hline FOOD AT HOME & $21: 67$ & $6: 9$ \\
\hline HOUSEHOLD OPERATIONS & $12: 99$ & $4: 5$ \\
\hline WOMEN'S CLOTHING & $5: 1$ & $3: 3$ \\
\hline MEN'S CLOT HING & $3: 83$ & $2: 4$ \\
\hline CHILDREN'S CLOTHING & $3: 57$ & $2: 2$ \\
\hline \hline VICES & $5: 53$ & $4: 5$ \\
\hline HOUSE HOLD NET INCOME* & $54 ; 867$ & $18 ; 600$ \\
\hline HUSBAND'S GROSS EARNINGS* & $41 ; 423$ & $19 ; 553$ \\
\hline WIFE'S GROSS EARNINGS* & $27 ; 822$ & $13 ; 343$ \\
\hline WIFE'S SHARE & $0: 40$ & $0: 12$ \\
\hline TOTAL NONDURABLE EXPENDITURE* & $30 ; 239$ & $9 ; 703$ \\
\hline \hline * All values in 1992 Canadian dollars. & \multicolumn{3}{|c|}{} \\
\hline
\end{tabular}

\begin{tabular}{|c|c|}
\hline & $\overline{\mathrm{MEAN}}$ \\
\hline ATLANTIC & 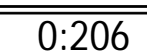 \\
\hline QUEBEC & $0: 183$ \\
\hline PRAIRIES & $0: 231$ \\
\hline B.C. & 0:077 \\
\hline HOMEOWNER & $0: 796$ \\
\hline CITY DWELLER & $0: 720$ \\
\hline HUSBAND'S AGE & $36: 1$ \\
\hline WIFE'S AGE & $33: 6$ \\
\hline NUMBER OF YOUNG CHILDREN & $0: 36$ \\
\hline NUMBER OF OLDER CHILDREN & $1: 45$ \\
\hline MORE THAN HIGH SCHOOL* & $0: 542$ \\
\hline FRANCOPHONE* & $0: 189$ \\
\hline ALLOPHONE* & $0: 153$ \\
\hline
\end{tabular}


D. Detailed results.

\begin{tabular}{|c|c|c|c|}
\hline \multicolumn{4}{|c|}{$\begin{array}{r}\text { Table D 1: Parameter Estimates of the Cal } \\
\text { Flat-slope- } \neq \text { at model } \\
\text { Food at home }\end{array}$} \\
\hline & Coed cient & Standard Error & T-Value \\
\hline Constant & 37.944 & 27.261 & 1.392 \\
\hline Age & 1.431 & 0.342 & 4.182 \\
\hline Age squared & 0.079 & 0.228 & 0.347 \\
\hline Number of young children & 1.519 & 0.294 & 5.165 \\
\hline Number of medium children & 2.560 & 0.166 & 15.463 \\
\hline Spouse age & 0.382 & 0.375 & 1.019 \\
\hline Husband Francophone & 0.335 & 0.489 & 0.685 \\
\hline Husband allophone & 1.132 & 0.388 & 2.917 \\
\hline House owner & -0.781 & 0.335 & -2.329 \\
\hline City residence & -0.030 & 0.283 & -0.107 \\
\hline Education beyond High School & 0.173 & 0.253 & 0.684 \\
\hline Region Atlantic & -1.897 & 1.101 & -1.723 \\
\hline Region Quebec & 0.188 & 0.650 & 0.289 \\
\hline Region Prairies & -1.165 & 0.670 & -1.740 \\
\hline Region British Columbia & -0.264 & 0.751 & -0.352 \\
\hline In (Price of Food) & 12.371 & 5.208 & 2.375 \\
\hline In (Price of Household Operations) & -0.232 & 7.680 & -0.030 \\
\hline In (P rice of Tobacco) & -4.428 & 1.692 & -2.618 \\
\hline In (Price of Alcohol) & 18.060 & 7.915 & 2.282 \\
\hline In (P rice of clothing) & -3.814 & 2.958 & -1.289 \\
\hline In (Price of R estaurant) & -4.086 & 5.485 & -0.745 \\
\hline In (Price of Gas) & 0.362 & 2.251 & 0.161 \\
\hline In (Price of Care) & -3.789 & 2.160 & -1.754 \\
\hline In (Price of Transportation) & -7.724 & 3.008 & -2.567 \\
\hline In (Price of Services) & 3.276 & 3.640 & 0.900 \\
\hline In (Price of Suppl) & -1.896 & 8.504 & -0.223 \\
\hline In (P rice of Recreation) & 8.101 & 6.825 & 1.187 \\
\hline In (Price of Furn) & -12.529 & 8.518 & -1.471 \\
\hline In (P rice of Carp) & -9.571 & 6.934 & -1.380 \\
\hline In (Total Expenditure) & 17.740 & 13.695 & 1.295 \\
\hline In (Total Expenditure) Squared & -4.253 & 1.999 & -2.127 \\
\hline Rho & -3.886 & 1.709 & -2.273 \\
\hline
\end{tabular}




\begin{tabular}{|c|c|c|c|}
\hline \multicolumn{4}{|c|}{$\begin{array}{r}\text { Table D 2: Parameter Estimates of the Carin } \\
\qquad \begin{array}{r}\text { Flat-slope- } \neq \text { at model } \\
\text { Household Operations }\end{array}\end{array}$} \\
\hline & Coec cient & Standard Error & T-Value \\
\hline Constant & 45.181 & 20.443 & 2.210 \\
\hline Age & -0.191 & 0.268 & -0.715 \\
\hline A ge squared & -0.128 & 0.174 & -0.732 \\
\hline Number of young children & 0.439 & 0.209 & 2.097 \\
\hline Number of medium children & 0.242 & 0.111 & 2.184 \\
\hline Spouse age & 0.962 & 0.275 & 3.501 \\
\hline Husband Francophone & -0.980 & 0.356 & -2.754 \\
\hline Husband allophone & -0.245 & 0.257 & -0.952 \\
\hline House owner & 2.611 & 0.248 & 10.528 \\
\hline City residence & -1.119 & 0.203 & -5.516 \\
\hline Education beyond High School & -0.236 & 0.181 & -1.304 \\
\hline Region Atlantic & 0.928 & 0.761 & 1.219 \\
\hline Region Quebec & -0.249 & 0.458 & -0.545 \\
\hline Region Prairies & -0.440 & 0.457 & -0.963 \\
\hline Region British Columbia & -1.092 & 0.527 & -2.072 \\
\hline In (Price of Food) & -5.997 & 3.694 & -1.624 \\
\hline In (Price of Household Operations) & 8.864 & 5.208 & 1.702 \\
\hline In (P rice of Tobacco) & -1.289 & 1.180 & -1.092 \\
\hline In (Price of Alcohol) & 2.932 & 5.593 & 0.524 \\
\hline In (P rice of clothing) & 1.221 & 2.005 & 0.609 \\
\hline In (P rice of R estaurant) & 1.846 & 3.867 & 0.477 \\
\hline In (P rice of $\mathrm{G}$ as) & -1.907 & 1.537 & -1.241 \\
\hline In (P rice of Care) & -2.117 & 1.547 & -1.368 \\
\hline In (Price of Transportation) & -1.751 & 2.076 & -0.844 \\
\hline In (Price of Services) & 3.179 & 2.461 & 1.292 \\
\hline In (Price of Suppl) & -4.737 & 5.945 & -0.797 \\
\hline In (Price of R ecreation) & -6.381 & 4.886 & -1.306 \\
\hline In (Price of Furn) & 4.473 & 5.924 & 0.755 \\
\hline In (P rice of Carp) & 4.953 & 5.052 & 0.980 \\
\hline In (Total Expenditure) & -25.455 & 10.559 & -2.411 \\
\hline In (Total Expenditure) Squared & 3.318 & 1.547 & 2.145 \\
\hline Rho & -2.524 & 1.273 & -1.982 \\
\hline
\end{tabular}




\begin{tabular}{|c|c|c|c|}
\hline \multicolumn{4}{|c|}{$\begin{array}{r}\text { Table D 3: Parameter Estimates of the Car } \\
\text { F lat-slope- } \neq \text { at model } \\
\text { Women's clothing }\end{array}$} \\
\hline & Coed cient & Standard Error & T-Value \\
\hline Constant & 6.745 & 12.944 & 0.521 \\
\hline Age & -0.089 & 0.183 & -0.486 \\
\hline Age squared & -0.180 & 0.103 & -1.737 \\
\hline Number of young children & -1.255 & 0.150 & -8.358 \\
\hline Number of medium children & -0.783 & 0.087 & -8.989 \\
\hline Spouse age & -0.029 & 0.228 & -0.125 \\
\hline Husband francophone & 0.411 & 0.267 & 1.536 \\
\hline Husband allophone & 0.565 & 0.221 & 2.560 \\
\hline House owner & -0.075 & 0.174 & -0.431 \\
\hline City residence & -0.127 & 0.154 & -0.825 \\
\hline Education beyond High School & -0.202 & 0.147 & -1.378 \\
\hline Region Atlantic & -0.576 & 0.644 & -0.895 \\
\hline Region Quebec & 0.110 & 0.345 & 0.319 \\
\hline Region Prairies & -0.063 & 0.372 & -0.170 \\
\hline Region B ritish Columbia & -0.785 & 0.429 & -1.832 \\
\hline In (Price of Food) & -1.887 & 3.097 & -0.609 \\
\hline In (Price of Household Operations) & 1.335 & 4.436 & 0.301 \\
\hline In (Price of Tobacco) & -1.495 & 0.925 & -1.616 \\
\hline In (Price of Alcohol) & 5.754 & 4.382 & 1.313 \\
\hline In (Price of clothing) & -1.535 & 1.686 & -0.910 \\
\hline In (Price of Restaurant) & 1.870 & 3.095 & 0.604 \\
\hline In (Price of Gas) & -1.147 & 1.250 & -0.918 \\
\hline In (Price of Care) & -1.036 & 1.211 & -0.856 \\
\hline In (Price of Transportation) & -0.333 & 1.688 & -0.197 \\
\hline In (Price of Services) & -1.829 & 2.078 & -0.880 \\
\hline In (Price of Suppl) & 1.073 & 4.671 & 0.230 \\
\hline In (Price of Recreation) & -1.759 & 3.915 & -0.449 \\
\hline In (Price of Furn) & 1.444 & 4.965 & 0.291 \\
\hline In (Price of Carp) & -1.304 & 3.902 & -0.334 \\
\hline In (Total Expenditure) & -1.171 & 6.241 & -0.188 \\
\hline In (Total Expenditure) Squared & 0.700 & 0.934 & 0.749 \\
\hline Rho & 3.314 & 0.887 & 3.736 \\
\hline
\end{tabular}




\begin{tabular}{|c|c|c|c|}
\hline \multicolumn{4}{|c|}{$\begin{array}{r}\text { Table D 4: Parameter Estimates of the Car } \\
\text { Flat-slope- } \neq \text { at model } \\
\text { Men's clothing }\end{array}$} \\
\hline & Coec cient & Standard Error & T-Value \\
\hline Constant & 26.000 & 9.528 & 2.729 \\
\hline Age & 0.007 & 0.132 & 0.051 \\
\hline A ge squared & -0.088 & 0.072 & -1.227 \\
\hline Number of young children & -0.509 & 0.112 & -4.537 \\
\hline Number of medium children & -0.332 & 0.061 & -5.429 \\
\hline Spouse age & -0.105 & 0.152 & -0.694 \\
\hline Husband francophone & 0.316 & 0.176 & 1.796 \\
\hline Husband allophone & 0.314 & 0.151 & 2.074 \\
\hline House owner & 0.013 & 0.133 & 0.095 \\
\hline City residence & -0.093 & 0.110 & -0.840 \\
\hline Education beyond High School & -0.350 & 0.105 & -3.337 \\
\hline Region Atlantic & 0.126 & 0.474 & 0.265 \\
\hline Region Quebec & 0.337 & 0.244 & 1.378 \\
\hline Region Prairies & 0.053 & 0.264 & 0.199 \\
\hline Region B ritish Columbia & -0.303 & 0.290 & -1.042 \\
\hline In (Price of Food) & 1.455 & 2.022 & 0.719 \\
\hline In (Price of Household Operations) & -1.332 & 3.070 & -0.434 \\
\hline In (P rice of Tobacco) & 0.335 & 0.684 & 0.490 \\
\hline In (Price of Alcohol) & 1.748 & 3.138 & 0.557 \\
\hline In (P rice of clothing) & -1.847 & 1.261 & -1.465 \\
\hline In (P rice of R estaurant) & -0.419 & 2.247 & -0.187 \\
\hline In (P rice of $\mathrm{G}$ as) & -1.425 & 0.883 & -1.613 \\
\hline In (P rice of Care) & -0.233 & 0.869 & -0.268 \\
\hline In (Price of Transportation) & 0.200 & 1.236 & 0.162 \\
\hline In (Price of Services) & -0.054 & 1.427 & -0.038 \\
\hline In (Price of Suppl) & 4.935 & 3.443 & 1.433 \\
\hline In (Price of R ecreation) & -6.468 & 2.713 & -2.384 \\
\hline In (Price of Furn) & 5.227 & 3.422 & 1.528 \\
\hline In (P rice of Carp) & -3.070 & 2.679 & -1.146 \\
\hline In (Total Expenditure) & -12.017 & 4.819 & -2.494 \\
\hline In (Total Expenditure) Squared & 2.093 & 0.728 & 2.873 \\
\hline Rho & -1.335 & 0.689 & -1.939 \\
\hline
\end{tabular}




\begin{tabular}{|c|c|c|c|}
\hline \multicolumn{4}{|c|}{$\begin{array}{l}\text { Table D 5: Parameter Estimates of the Caring Collective Model. } \\
\qquad \begin{array}{l}\text { F lat-slope } \neq \text { at model } \\
\text { K id's clothing }\end{array}\end{array}$} \\
\hline & Coeф cient & Standard Error & $\overline{\text { T-Value }}$ \\
\hline Constant & -0.188 & 8.328 & -0.023 \\
\hline Age & 0.205 & 0.124 & 1.651 \\
\hline Age squared & -0.193 & 0.082 & -2.345 \\
\hline Number of young children & 0.183 & 0.111 & 1.655 \\
\hline Number of medium children & 1.037 & 0.067 & 15.390 \\
\hline Spouse age & -0.179 & 0.138 & -1.298 \\
\hline Husband francophone & 0.117 & 0.158 & 0.745 \\
\hline Husband allophone & 0.025 & 0.124 & 0.202 \\
\hline House owner & -0.071 & 0.102 & -0.697 \\
\hline City residence & -0.252 & 0.098 & -2.585 \\
\hline Education beyond High School & 0.043 & 0.085 & 0.502 \\
\hline Region Atlantic & 0.570 & 0.354 & 1.612 \\
\hline Region Quebec & 0.016 & 0.197 & 0.082 \\
\hline Region Prairies & 0.191 & 0.224 & 0.854 \\
\hline Region B ritish Columbia & -0.343 & 0.237 & -1.445 \\
\hline In (Price of Food) & 0.469 & 1.708 & 0.274 \\
\hline In (Price of Household Operations) & -4.568 & 2.438 & -1.873 \\
\hline In (Price of Tobacco) & -0.860 & 0.570 & -1.508 \\
\hline In (Price of Alcohol) & -0.082 & 2.629 & -0.031 \\
\hline In (Price of clothing) & -2.782 & 1.015 & -2.741 \\
\hline In (Price of Restaurant) & 2.836 & 1.779 & 1.594 \\
\hline In (Price of Gas) & -0.586 & 0.711 & -0.825 \\
\hline In (Price of Care) & 0.576 & 0.726 & 0.794 \\
\hline In (Price of Transportation) & -0.087 & 0.967 & -0.090 \\
\hline In (Price of Services) & -0.838 & 1.133 & -0.739 \\
\hline In (Price of Suppl) & 6.626 & 2.787 & 2.377 \\
\hline In (Price of Recreation) & 2.586 & 2.349 & 1.101 \\
\hline In (Price of Furn) & -2.007 & 2.790 & -0.719 \\
\hline In (P rice of Carp) & -0.690 & 2.394 & -0.288 \\
\hline In (Total Expenditure) & -0.173 & 4.103 & -0.042 \\
\hline In (Total Expenditure) Squared & -0.001 & 0.608 & -0.001 \\
\hline Rho & 1.542 & 0.585 & 2.637 \\
\hline
\end{tabular}




\begin{tabular}{|c|c|c|c|}
\hline \multicolumn{4}{|c|}{$\begin{array}{l}\text { Table D 6: Parameter E stimates of the Caring Collective Model. } \\
\qquad \text { Flat-slope } \neq \text { at model } \\
\text { Vices }\end{array}$} \\
\hline & Coed cient & Standard Error & T-Value \\
\hline Constant & 7.109 & 23.716 & 0.300 \\
\hline Age & -0.132 & 0.296 & -0.444 \\
\hline A ge squared & -0.013 & 0.178 & -0.072 \\
\hline Number of young children & -0.764 & 0.229 & -3.334 \\
\hline Number of medium children & -0.242 & 0.130 & -1.853 \\
\hline Spouse age & -0.333 & 0.346 & -0.962 \\
\hline Husband francophone & 0.244 & 0.347 & 0.702 \\
\hline Husband allophone & -1.350 & 0.285 & -4.746 \\
\hline House owner & -1.423 & 0.275 & -5.178 \\
\hline City residence & 0.433 & 0.220 & 1.972 \\
\hline Education beyond High School & 1.223 & 0.207 & 5.900 \\
\hline Region Atlantic & -0.684 & 0.886 & -0.772 \\
\hline Region Quebec & -0.207 & 0.485 & -0.426 \\
\hline Region Prairies & -0.440 & 0.533 & -0.826 \\
\hline Region British Columbia & -0.379 & 0.579 & -0.654 \\
\hline In (Price of Food) & 0.834 & 4.152 & 0.201 \\
\hline In (Price of Household Operations) & 0.941 & 5.766 & 0.163 \\
\hline In (P rice of Tobacco) & -0.674 & 1.272 & -0.530 \\
\hline In (Price of Alcohol) & 7.868 & 6.400 & 1.230 \\
\hline In (Price of clothing) & -4.686 & 2.387 & -1.963 \\
\hline In (P rice of Restaurant) & -3.230 & 4.381 & -0.737 \\
\hline In (P rice of Gas) & 1.150 & 1.608 & 0.715 \\
\hline In (Price of Care) & -2.398 & 1.750 & -1.370 \\
\hline In (Price of Transportation) & -1.816 & 2.376 & -0.764 \\
\hline In (Price of Services) & 2.749 & 2.679 & 1.026 \\
\hline In (Price of Suppl) & -4.300 & 6.766 & -0.636 \\
\hline In (Price of Recreation) & -1.287 & 5.573 & -0.231 \\
\hline In (Price of Furn) & 7.371 & 7.018 & 1.050 \\
\hline In (P rice of Carp) & -4.336 & 5.658 & -0.766 \\
\hline In (Total Expenditure) & 5.156 & 12.245 & 0.421 \\
\hline In (Total Expenditure) Squared & -0.838 & 1.791 & -0.468 \\
\hline R ho & -1.424 & 1.390 & -1.024 \\
\hline
\end{tabular}




\section{R eferences}

[1] Apps, Patricia and Ray Rees (1988), "Taxation and the household", J ournal of Public Economics, 35, 355-69.

[2] Becker, Gary S. (1991), A Treatise on the Family, Cambridge and London: Harvard University Press.

[3] Bergstrom, Theodore C. (1989) "A fresh look at the Rotten Kid Theorem and other household mysteries", J ournal of Political Economy, 97(5), pages 1138-59.

[4] Bergstrom, Theodore, Lawrence Blume and Hal Varian (1986), "On the private provision of public goods", J ournal of Public Economics, 29, p25-49.

[5] Bernheim, Douglas (1986), "On the voluntary and involuntary provision of public goods", A merican Economic Review, 76(4), 789-793.

[6] Bourguignon, François (1984), "R ationalité individuelle ou rationalité strategique: le cas de l'oxre familiale de travail", Revue E conomique, 35(1), 147-62.

[7] Bourguignon, Francois; Martin Browning; Pierre-André Chiappori and Valérie Lechene (1993), "Intra-household allocation of consumption: a model and some evidence from French data", Annales d'E conomie et de Statistique, 137-56.

[8] Bourguignon, Francois; Martin B rowning and Pierre-A ndréChiappori (1995), "T he collective approach to household behaviour", mimeo, DELTA, Paris.

[9] Browning, Martin (2000), "The saving behaviour of a two person household", Scandinavian J ournal of Economics, Vol 102, n2, p235-52.

[10] Browning, Martin (1995), "Saving and the intra-household distribution of income: an empirical investigation", Ricerche E conomiche, 48, 277-92.

[11] Browning, Martin; François Bourguignon; Pierre-André Chiappori and Valérie Lechene (1994), "Income and outcomes: a structural model of intrahousehold allocation", J ournal of Political Economy, 102(6), 1067-96.

[12] Browning, Martin and Pierre-André Chiappori, (1998), " $E \$$ cient intrahousehold allocation: a characterisation and tests", Econometrica, Vol66, n6, p1241-78. 
[13] Chiappori, PierreAndré (1988), "Rational household labor supply", Econometrica, 56(1), 63-90.

[14] Chiappori, Pierre-A ndré (1992), "Collective labor supply and welfare", J ournal of Political Economy, 100(3), 437-67.

[15] K apteyn, A rie and Peter Kooreman (1990), "On the empirical implementation of some game theoretic models of household labour supply", J ournal of Human Resources, 25(4), 584-598.

[16] Konrad, Kai and Kjell Erik Lommerud (1995), "Family policy with noncooperative families", Scandinavian J ournal of Economics, 97(4), 581-601.

[17] Leuthold, J ane (1968), "An empirical study of formula income transfers and the work decisions of the poor", J ournal of Human Resources, 3, 312-23.

[18] Lundberg, Shelly and Robert A. Pollak (1993), "Separate spheres bargaining and the marriage market", J ournal of Political E conomy, 101, 988-1010.

[19] Lundberg, Shelly; Robert A. Pollak and Terence Wales (1997), "Do husbands and wives pool their resources? Evidence from the U.K.Child B ene..t", J ournal of Human Resources, Summer 97, Vol32, n3, p463-80.

[20] Manser, Marilyn and Murray Brown (1980), "Marriage and household de cision making: a bargaining analysis", International Economic Review, 21(1),31-44.

[21] McElroy, Marjorie B. (1990), "The empirical content of Nash bargained household behavior", J ournal of Human Resources, 25(4), 559-83.

[22] M CE Iroy, M arjorie B. and M ary J ean Horney (1981), "Nash bargained house hold decisions: toward a generalization of the theory of demand", International Economic Review, 22(2), 333-49.

[23] Phipps, Shelley and Peter Burton (1998), "What's mine is yours? The inłuence of male and female incomes on patterns of household expenditure", E conomica, Vol65, n260, p599-613..

[24] Rasheed, Wasif (1996) "A noncooperative and cooperative nash bargaining model of household behaviour", mimeo, M cM aster U niversity. 
[25] Samuelson, Paul (1956), "Community indixerence curves", Quarterly J ournal of Economics.

[26] Schultz, T. Paul (1990), "Testing the neoclassical model of family labor supply and fertility", J ournal of Human Resources, 25(4), 599-634.

[27] Thomas, Duncan (1990), "Intra household resource allocation: an inferential approach" J ournal of Human Resources, 25(4), 635-64.

[28] Ulph, David (1988), "A general non-cooperative Nash model of household consumption behaviour", Working paper 88-205, Department of Economics, University of Bristol.

[29] Warr, Peter (1983) "The private provision of a public good is independent of the distribution of income", Economic Letters, 13, 207-11.

[30] Woolley, Frances (1993), "A Cournot-Nash model of family decision making", mimeo, Carleton University. 

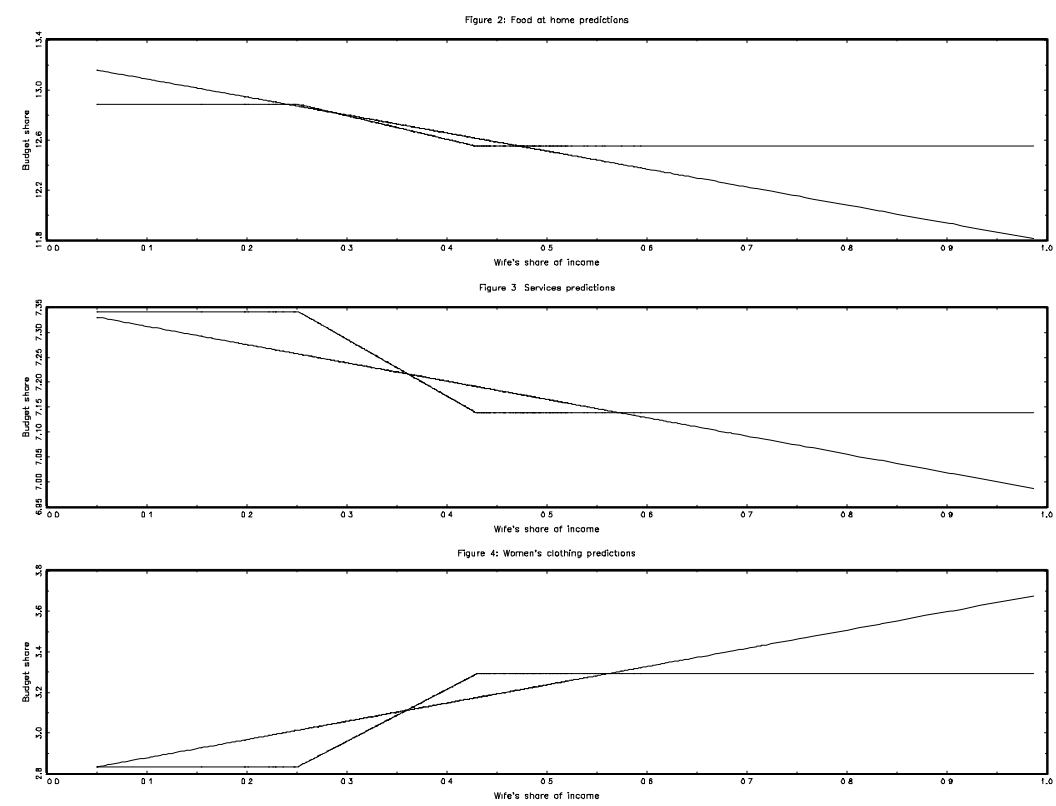

F igure 5: 

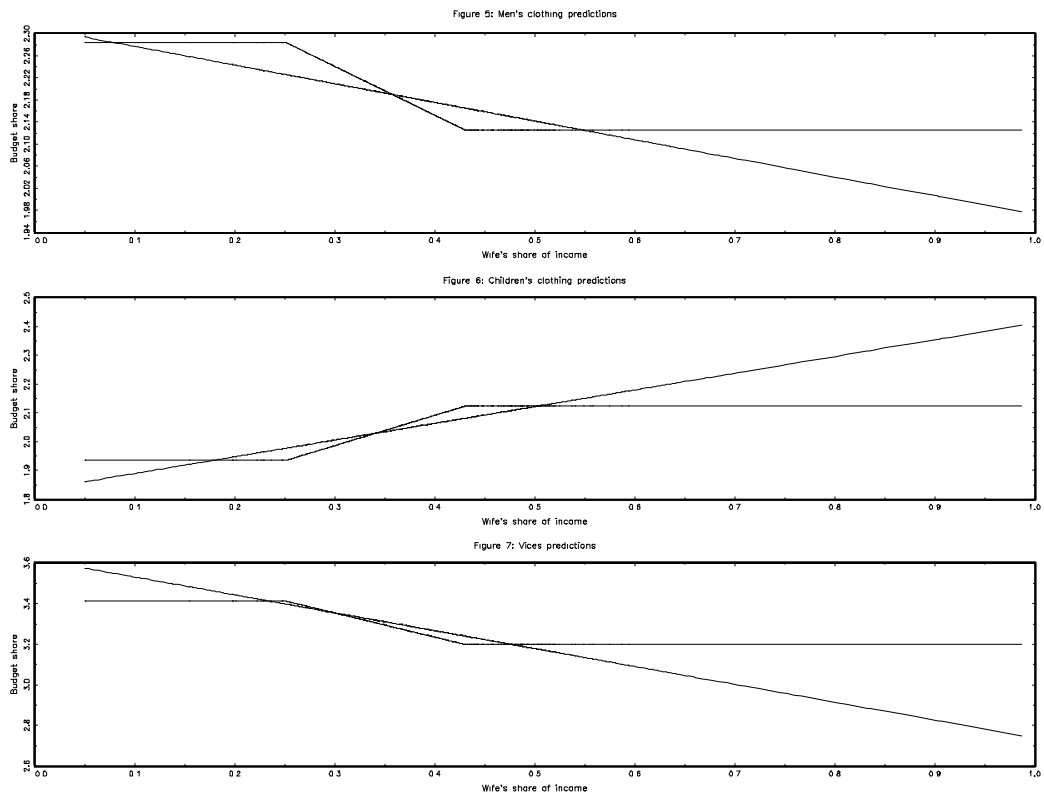

Figure 6: 